\title{
ANALISIS KEMISKINAN DAN KETIMPANGAN DISTRIBUSI PENDAPATAN DI PROVINSI SUMATERA UTARA (TAHUN 2016-2020)
}

\author{
Dwi Wulandari ${ }^{1}$, Fila Destia Dinanti ${ }^{2}$, dan Patricia Intan Karonesia Br Tarigan ${ }^{3}$ \\ Pendidikan Ekonomi, Fakultas Ekonomi, Universitas Negeri Medan \\ Email: filadestiadina@gmail.com
}

\begin{abstract}
ABSTRAK
Kemiskinan dan ketimpangan selalu menjadi masalah di setiap negara sedang berkembang, bahkan di negara maju pun juga. Di Indonesia tingginya jumlah penduduk miskin dipengaruhi oleh berbagai macam factor, diantaranya adanya ketimpangan dalam pendistribusian pendapatan antar satu provinsi dengan provinsi lainnya.

Penelitian ini bertujuan untuk menganalisis seberapa besar seberapa besar tingkat kemiskinan dan ketimpangan distribusi pendapatan yang terjadi di Sumatera Utara tahun 20162020. Metode analisis data dalam penelitian ini adalah pendekatan deskriptif kuantitatif. Jenis data yang digunakan adalah data sekunder yang diperoleh dari Badan Pusat Statistik Provinsi Sumatera Utara dari tahun 2016 hingga tahun 2020.

Setelah dilakukan analisis dapat diperoleh hasil bahwa ketimpangan distribusi pendapatan Provinsi Sumatera Utara yang dilihat dari Gini Ratio selama lima tahun pengamatan rata-rata koefisien berada di atas angka 0,310 yang artinya ketimpangan di Provinsi Sumatera Utara masih tergolong rendah $(0<\mathrm{GR}<0,4)$ karenanya pembangunan ekonomi dan distribusi pendapatan di Provinsi Sumatera Utara relatif merata, dan nilai Gini Ratio tertinggi selama tahun pengamatan terjadi di September 2017.

\section{Kata Kunci: Kemiskinan dan Ketimpangan distribusi pendapatan. PENDAHULUAN}

Pembangunan ekonomi yang dilaksanakan bangsa Indonesia meliputi seluruh aspek perekonomian masyarakat, baik kehidupan masyarakat pedesaan maupun masyarakat perkotaan, dengan tujuan utama memperbaiki dan meningkatkan taraf hidup seluruh rakyat Indonesia. Pembangunan ekonomi tersebut dilaksanakan dengan menitikberatkan pada upaya pertumbuhan sektor ekonomi dengan memanfaatkan segala potensi yang dimiliki, baik potensi sumber daya alam maupun sumber daya manusianya.

Tetapi dari sisi sosial, pertumbuhan ekonomi yang tinggi ternyata tidak dinikmati oleh seluruh penduduk Indonesia sesuai kebutuhan mereka sehingga terjadi ketimpangan ekonomi
\end{abstract}


antar daerah. Kesenjangan atau ketimpangan antar daerah merupakan konsekuensi logis dari proses pembangunan yang merupakan suatu tahap perubahan dalam pembangunan itu sendiri. Perbedaan tingkat kemajuan antar daerah yang berlebihan akan menyebabkan pengaruh yang merugikan dan mendominasi pengaruh yang menguntungkan terhadap pertumbuhan daerah. Selain pertumbuhan ekonomi dan ketimpangan ekonomi, proses pembangunan juga bertujuan untuk menghapus dan mengurangi tingkat kemiskinan, ketimpangan pendapatan dan pengangguran.

Menurut Remi dan Tjiptoherijanto (2002), penyebab utama kemiskinan suatu rumah tangga adalah rendahya pendapatan yang mereka terima. Sedangkan karakteristik penduduk miskin tersebut antara lain adalah memiliki rata-rata jumlah tanggungan yang banyak. Jumlah anggota dalam rumah tangga adalah indikasi yang dominan dalam menentukan miskin atau ketidakmiskinannya rumah tangga. Namun, penyebab tersebut tidak sama untuk setiap kondisi.

Jumlah penduduk miskin, yakni penduduk yang berada dibawah Garis kemiskinan, di Sumatera Utara pada bulan maret 2018 sebesar 1.324.980 orang (11,51\%). Dibandingkan dengan penduduk miskin pada bulan maret 2017 yang berjumlah 1.326 .800 orang (12,55 \%), berarti jumlah penduduk miskin di Provinsi Sumatera Utara berkurang sebanyak 114.100 orang (1,04\%). Selama periode Maret 2017 - Maret 2018, penduduk miskin di daerah pedesaan berkurang 40.400 orang $(0,73 \%)$, sementara di daerah perkotaan berkurang 73.700 orang $(1,40$ \%). Menurut Badan Pusat Statistik Sumatera Utara pada November 2018, garis kemiskinan Sumatera Utara secara total sebesar Rp. 366.137 perkapita perbulan. Untuk daerah perkotaan, garis kemiskinannya Rp. 369.878 dan untuk daerah pedesaan sebesar Rp. 352.637 perkapita perbulan. Sehingga dari bulan Maret sampai September kemiskinan dan indeks keparahan menunjukan kecenderungan meningkat. Besarnya jumlah penduduk miskin tersebut berpotensi menciptakan permasalahan sosial yang rumit, seperti pengangguran, munculnya ketimpangan dan kecemburuan sosial, kebodohan, kenakalan remaja, terganggunya stabilitas sosial politik, dan dampak-dampak lainnya, maka pada gilirannya dapat menghambat perkembangan ekonomi Kota Medan sekaligus menyulitkan terwujudnya Kota Medan yang bermartabat, Sejahtera dan berkeadilan. Kemiskinan dapat dilihat dari ketidakmampuan orang untuk memenuhi kebutuhan sandang, pangan, papan serta akses terhadap kesehatan maupun pendidikan yang berkaitan dengan daya beli. Kemiskinan juga terkait dengan ketersediaan sumber daya alam dan pengetahuan yang dimiliki serta perilaku hidup masyarakat setempat.

Masalah kemiskinan akan melahirkan ketimpangan distribusi pendapatan, yaitu yang terjadi antar perdesaan dengan perkotaan. Rendahnya tingkat pendidikan dan keterampilan 
yang dimiliki oleh penduduk juga menyebabkan mereka kesulitan untuk memasuki pekerjaan formal dan mempunyai pekerjaan yang dapat memberikan pendapatan yang memadai. Distribusi pendapatan suatu daerah yang tidak merata, tidak akan menciptakan kemakmuran bagi masyarakatnya secara umum. Sistem distribusi yang tidak merata hanya akan menciptakan kemakmuran bagi golongan tertentu saja. Begitu pula sebaliknya, distribusi pendapatan yang merata akan menciptakan kemakmuran bagi seluruh lapisan masyarakatnya. Berdasarkan pada uraian latar belakang di atas, maka permasalahan yang menjadi konsentrasi pada penelitian ini adalah seberapa besar tingkat kemiskinan dan ketimpangan distribusi pendapatan yang terjadi di Sumatera Utara.

\section{KAJIAN PUSTAKA}

\section{Kemiskinan}

Kuncoro (Prawoto, 2019), mendefinisikan kemiskinan dengan kondisi masyarakat yang tidak mampu untuk memenuhi standar hidup minimumnya. Arsyad (Prawoto, 2019) mendefinisikan kemiskinan dengan kondisi masyarakat yang tidak atau belum mampu untuk ikut serta dalam proses perubahan yang disebabkan ketidakmampuannya dalam kepemilikan faktor produksi maupun kualitas produksi yang memadai sehingga tidak mendapatkan manfaat dari proses pembangunan yang sedang terjadi. Ketidakmampuan tersebut dapat disebabkan oleh pengaruh dari luar (external factors) maupun pengaruh dari dalam (internal factors). Pengaruh dari luar dapat disebabkan oleh kondisi perekonomian suatu negara yang memburuk maupun kebijakan-kebijakan pemerintah yang belum tepat sasaran dalam menurunkan angka kemiskinan, sedangkan pengaruh dari dalam dapat disebabkan karena pasrah dengan keadaan atau kurangnya usaha dalam meningkatkan kesejahteraanya (Prawoto, 2019).

Menurut Nurwati (Mukhamad, 2018) kemiskinan merupakan masalah sosial yang terus ada di kehidupan masyarakat. Masalah kemiskinan sangatlah lama, dan dalam waktu yang panjang, sama seperti halnya dengan usia manusia itu sendiri, dan unsur pokok permasalahanya adalah menyangkut berbagai macam bentuk atau karakter kehidupan manusia. Dengan kata lain bahwa kemiskinan ini merupakan masalah kehidupan yang sifatnya global atau mendunia, artinya masalah kemiskinan sudah menjadi perhatian dunia, dan masalah tersebut ada di semua negara, walaupun dampak dari kemiskinan sangatlah berbeda-beda (Mukhamad, 2018).

\section{Jenis Kemiskinan}

Menurut Arsyad dan Todaro (Prawoto, 2019) kemiskinan di bagi menjadi empat jenis yaitu: 
a. Kemiskinan absolut adalah ketidakmampuan masyarakat dalam memenuhi standar minimumnya seperti kebutuhau dasar yang meliputi kesehatan, pendidikan, sandang, pangan, papan, dan apa yang melekat pada diri mereka agar tetap hidup dan bekerja .

b. Kemiskinan relatif adalah kemiskinan yang berkaitan dengan membandingkan pendapatan dari kelompok masyarakat yang berpenghasilan rendah dengan kelompok masyarakat yang berpenghasilan tinggi.

c. Kemiskinan structural dan ilmiah dapat terjadi jika tatanan kehidupan dalam masyarakat tidak adil atau tidak memihak pada masyarakat miskin akan memberikan dampak negatif yaitu melanggengkan kemiskinan itu sendiri. Ketidakadilan pada tatanan sosial akan mempersulit penduduk miskin untuk meningkatkan kualitas hidupnya dan rneningkatkan kesejahteraannya agar dapat hidup layak dan bermartabat sebagai manusia.

d. Kemiskinan kultural adalah ketidakmampuan dari suatu penduduk atau seseorang dalam kehidupan bermasyarakat yang disebabkan pada nilai-nilai adat dan budaya dari suatu daerah, membuat penduduk atau seseorang tersebut terbelunggu pada kemiskinan.

\section{Penyebab Kemiskinan}

Kuncoro mengidentifikasi bahwa terjadinya kemiskinan disebabkan oleh tiga hal. Pertama, perbedaan kepemilikan atas sumber daya alam yang mengakibatkan perbedaan pendapatan, kedua, kualitas sumberdaya rnanusia (produktivitas, pendapatan dll) yang berbeda antara satu dengan yang lain dapat rnengindikasikan kemiskinan, dan ketiga, perbedaan akses pada modal (Prawoto, 2019).

Menurut Suwadi (Mukhamad, 2018) kemiskinan di sebabkan oleh dua hal antara lain, yang pertama Kemiskinan di sebabkan karena sifat alami, sifat yang timbul dari perilaku masyarakat atau seseorang yaitu :

a. Keterbatasan sumber daya modalKeterbatasan sumber daya manusia (SDM) dapat di artikan kualitas sumber daya manusia misalkan keterampilan, pendidikan, dan pengetahuan.

b. Tempat atau letak geografis suatu wilayah yang terpencil dan yang sulit untuk di jangkau, yang mengakibatkan sulit berinteraksi dengan penduduk yang maju.

Yang kedua yaitu Kemiskinan yang di sebabkan karena kebijakan pembangunan atau kebijakan pemerintah, dapat di lihat dari berbagai aspek yaitu : 
a. Pembangunan yang kurang memperhatikan kawasan atau wilayah yang terpencil dan sulit di jangkau.

b. Adanya ketimpangan antara pembangunan di wilayah desa maupun kota.

c. Kurang memperhatikan usaha maupun produk masyarakat yang berskala kecil atau usaha mikro ekonomi.

\section{Ketimpangan Distribusi Pendapatan}

Distribusi pendapatan mencerminkan ketimpangan atau meratanya hasil pembangunan suatu daerah atau negara, baik yang diterima masing-masing orang ataupun dari kepemilikan factor-faktor produksi dikalangan penduduknya (HAKIKI, 2015). Ketimpangan distribusi pendapatan merupakan masalah perbedaan pendapatan antara masyarakat atau perbedaan pendapatan antara daerah yang maju dengan daerah yang tertinggal. Semakin besar jurang pendapatan maka semakin besar pula variasi dalam distribusi pendapatan. Ketimpangan distribusi pendapatan akan menyebabkan terjadinya disparitas antar daerah. Hal tersebut tidak dapat dihindari karena adanya efek perembesan ke bawah (trickle down effect) dari output secara nasional terhadap masyarakat mayoritas yang tidak terjadi secara sempurna (Hikmah, 2021).

\section{Faktor-Faktor yang Mempengaruhi Ketimpangan Distribusi Pendapatan}

Menurut Adelman dan Moris dalam (Hikmah, 2021) mengemukakan delapan faktor yang menyebabkan ketimpangan distribusi pendapatan di negara sedang berkembang, yakni :

1. Pertambahan penduduk yang tinggi mengakibatkan menurunnya pendapatan perkapita.

2. Inflasi dimana pendapatan uang bertambah tetapi tidak diikuti secara proporsional dengan pertambahan produksi barangbarang.

3. Ketidakmerataan pembangunan antar daerah

4. Investasi yang banyak dalam proyek-proyek pada modal (capital intensive) sehingga persentase pendapatan modal dari harta tambah besar dibandingkan dengan persentase pendapatan yang berasal dari kerja sehingga pengangguran bertambah.

5. Rendahnya mobilitas sosial.

6. Pelaksanaan kebijaksanaan industry substitusi impor yang mengakibatkan kenaikan harga barang-barang hasil untuk melindungi usaha-usaha golongan kapitalis.

7. Memburuknya nilai tukar (term off trade) bagi negara sedang berkembang dalam perdagangan dengan negara-negara maju sebagai akibat ketidaksetiaan permintaan negara-negara pada barang-barang ekspor negara sedang berkembang. 
8. Hancurnya industri-industri kerajinan rakyat seperti pertukangan, industri rumah tangga, dan lain-lain.

\section{METODE PENELITIAN}

Ruang lingkup penelitian ini yaitu meneliti kemiskinan dan ketimpangan distribusi pendapatan serta factor-faktor penyebabnya di Provinsi Sumatera Utara. Metode analisis data dalam penelitian ini adalah pendekatan deskriptif kuantitatif. Jenis data yang digunakan adalah data sekunder yang diperoleh dari Badan Pusat Statistik Provinsi Sumatera Utara dari tahun 2016 hingga tahun 2020.

\section{HASIL DAN PEMBAHASAN}

\section{Jumlah dan Persentase Penduduk Miskin}

Berikut ini adalah data jumlah penduduk miskin dan persentase penduduk yang diperoleh dari Badan Pusat Statistik Provinsi Sumatera Utara tahun 2016-2020.

\section{Tabel 1}

Jumlah dan Persentase Penduduk Miskin Sumatera Utara Tahun 2016-2020 


\begin{tabular}{|c|c|c|c|c|}
\hline \multicolumn{5}{|c|}{$\begin{array}{c}\text { Jumlah dan Presentase Penduduk Miskin Sumatera Utara } \\
\text { Tahun 2016-2020 }\end{array}$} \\
\hline Daerah/tahun & $\begin{array}{c}\text { Jumlah } \\
\text { penduduk } \\
\text { Miskin } \\
\text { (ribu } \\
\text { orang) }\end{array}$ & $\begin{array}{c}\text { Persentase } \\
\text { Penduduk } \\
\text { Miskin }\end{array}$ & $\begin{array}{l}\text { Perubahan } \\
\text { Jumlah } \\
\text { Penduduk } \\
\text { Miskin } \\
\text { (ribu jiwa) }\end{array}$ & $\begin{array}{c}\text { Perubahan } \\
\text { Persentase } \\
\text { Penduduk } \\
\text { Miskin }\end{array}$ \\
\hline $\begin{array}{l}\text { Tahun } 2016 \\
\text { Perkotaan + Perdesaan } \\
\text { Maret } 2016 \\
\text { September } 2016\end{array}$ & $\begin{array}{l}1455,95 \\
1452,55 \\
\end{array}$ & $\begin{array}{l}10,35 \\
10,27\end{array}$ & $\begin{array}{c}3,40 \\
(1,32)\end{array}$ & $\begin{array}{l}(0,08) \\
(0,05)\end{array}$ \\
\hline $\begin{array}{l}\text { Tahun } 2017 \\
\text { Perkotaan + Perdesaan } \\
\text { Maret } 2017 \\
\text { September } 2017\end{array}$ & $\begin{array}{l}1453,87 \\
1326,57\end{array}$ & $\begin{array}{c}10,22 \\
9,28\end{array}$ & $\begin{array}{c}(127,3) \\
1,59\end{array}$ & $\begin{array}{l}(1,00) \\
(0,06)\end{array}$ \\
\hline $\begin{array}{l}\text { Tahun } 2018 \\
\text { Perkotaan + Perdesaan } \\
\text { Maret } 2018 \\
\text { September } 2018 \\
\end{array}$ & $\begin{array}{l}1324,98 \\
1291,99 \\
\end{array}$ & $\begin{array}{l}9,22 \\
8,94\end{array}$ & $\begin{array}{c}(33) \\
(9,95)\end{array}$ & $\begin{array}{l}(0,28) \\
(0,11)\end{array}$ \\
\hline $\begin{array}{l}\text { Tahun } 2019 \\
\text { Perkotaan + Perdesaan } \\
\text { Maret } 2019 \\
\text { September } 2019\end{array}$ & $\begin{array}{l}1282,04 \\
1260,50 \\
\end{array}$ & $\begin{array}{l}8,83 \\
8,63\end{array}$ & $\begin{array}{l}(21,54) \\
(22,79)\end{array}$ & $\begin{array}{l}(0,02) \\
(0,12)\end{array}$ \\
\hline $\begin{array}{l}\text { Tahun } 2020 \\
\text { Perkotaan + Perdesaan } \\
\text { Maret } 2020 \\
\text { September } 2020\end{array}$ & $\begin{array}{l}1283,29 \\
1360,00\end{array}$ & $\begin{array}{l}8,75 \\
9,25\end{array}$ & 76,71 & 0,05 \\
\hline
\end{tabular}

Pada tahun 2016 jumlah penduduk miskin periode maret berada pada angka 1.455,95 ribu jiwa dan presentase penduduk miskin berada pada angka 10,35\%. Sedangkan, pada periode September 2016 jumlah penduduk miskin mengalami penurunan sebesar 3,40 ribu jiwa, dari 1.455,95 ribu jiwa menjadi 1.452,55 ribu jiwa. Presentase penduduk miskin juga berkurang sebesar $0,08 \%$ dari $10,35 \%$ menjadi $10,27 \%$.

Pada tahun 2017 jumlah penduduk miskin periode maret berada pada angka 1.453,87 ribu jiwa, hal ini menunjukkan bahwa secara absolut jumlah penduduk miskin berkurang jika dibandingkan dengan periode September 2016, yakni sebesar 1,32 ribu jiwa dari 1.452,55 ribu jiwa menjadi 1.453,87 ribu jiwa. Untuk presentase penduduk miskin periode maret 2019 juga mengalami penurunan jika dibandingkan periode September 2016 yakni sebesar 0,05\% dari 10,27\% menjadi 10,22\%. Penurunan juga dialami pada periode September 2017 yaitu dengan berkurangnya jumlah penduduk miskin sebesar 127,3 ribu jiwa dari 1.453,87 ribu jiwa pada Maret 2017 menjadi 1.326,57 ribu jiwa pada September 2017. Selain itu presentase penduduk miskin juga berkurang sebesar $1 \%$ dari $10,22 \%$ menjadi $9,28 \%$. 
Pada tahun 2018 jumlah penduduk miskin periode maret mengalami penurunan jika dibandingkan periode September 2017 yakni sebesar 1,59 ribu jiwa. Dari 1.326,57 ribu jiwa menjadi 1.324,98 ribu jiwa. Presentase penduduk miskin juga mengalami penurunan sebesar 0,06\% dari 9,28\% pada September 2017 menjadi 9,22\% pada Maret 2018. Untuk periode September 2018 jumlah penduduk miskin mengalami penurunan sebesar 33 ribu jiwa, yakni dari 1.324,98 ribu jiwa pada Maret 2018 menjadi 1.291,99 ribu jiwa pada September 2018. Presentase penduduk miskin mengalami penurunan sebesar 0,28\%, dari 9,22\% pada Maret 2018 menjadi 8,94\% pada September 2018.

Pada tahun 2019 jumlah penduduk miskin periode maret mengalami penurunan jika dibandingkan dengan periode September 2018, yakni sebesar 9,95 ribu jiwa. Dari 1.291,99 ribu jiwa menjadi 1.282,04 ribu jiwa. Presentase jumlah penduduk miskin juga mengalami penurunan sebesar 0,11\% dari 8,94 \% pada September 2018 menjadi 8,83\% pada Maret 2019. Untuk periode September 2019 jumlah penduduk miskin mengalami penrunan sebesar 21,54 ribu jiwa. Dari 1.282,04 ribu jiwa pada Maret 2019 menjadi 1.260,50 ribu jiwa pada September 2019. Presentase jumlah penduduk miskin mengalami penurunan sebesar $0,02 \%$ dari $8,83 \%$ menjadi $8,63 \%$.

Pada tahun 2020 jumlah penduduk miskin mengalami peningkatan jika dibandingkan periode September 2019 yakni sebesar 22,79 ribu jiwa dari 1.260,50 ribu jiwa menjadi 1.283,29 ribu jiwa. Presentase jumlah penduduk miskin meningkat sebesar $0,12 \%$ yakni dari $8,63 \%$ menjadi 8,75\% kenaikan ini juga terjadi pada September 2020. Jumlah penduduk miskin periode September 2020 meningkat menjadi 76,71 ribu jiwa dari 1.283,29 ribu jiwa menjadi $1.360,00$ ribu jiwa. Presentase penduduk miskin juga mengalami peningkatan sebesar $0,05 \%$ dari $8,75 \%$ menjadi $9,25 \%$.

\section{Ketimpangan Distribusi Pendapatan}

Distribusi pendapatan merupakan ukuran yang dapat digunakan untuk melihat tingkat ketimpangan dalam distribusi pendapatan penduduk. Menurut Todaro Ketimpangan Distribusi Pendapatan adalah distribusi yang tidak proporsional dari pendapatan nasional total diantara berbagai rumah tangga dalam negara (Tiara, 2016). Terdapat berbagai macam alat yang dapat dijumpai dalam mengukur tingkat ketimpangan distribusi pendapatan penduduk (Distribution Income Disparities), diantaranya yaitu Kurva Lorenz (Lorenz Curve), Rasio Gini, dan Regional Income Disparities (Tiara, 2016). Dalam penelitian ini untuk mengukur tingkat ketimpangan pendapatan secara menyeluruh maka alat yang digunakan adalah Rasio Gini. Gini rasio adalah ukuran ketimpangan pendapatan agregat yang angkanya berkisar antara nol (pemerataan 
sempurna) hingga satu (ketimpangan sempurna) (Tiara, 2016). Koefisien Gini 0 menunjukan adanya pemerataan pendapatan yang sempurna, atau setiap orang memiliki pendapatan yang sama. Sedangkan, Koefisien Gini 1 menunjukan ketimpangan yang sempurna, atau satu orang mendapatkan semua pendapatan yang ada sementara orang lain tidak mendapatkan apa- apa. Jadi kebijakan untuk mengurangi ketimpanagn pendapatan adalah mengupayakan Koefisien Gini populasi mendekati nilai 0 yang dimana akan menunjukkan adanya pemerataan distribusi pendapatan antar penduduk. Klasifikasi ketimpangan distribusi pendapatan adalah sebagai berikut:

\section{Tabel 2}

Nilai Gini Ratio dan Distribusi Pendapatan/ Ketimpangan

\begin{tabular}{|l|l|}
\hline Nilai Koefisien GR & Distribusi Pendapatan \\
\hline GR $=0$ & Merata Sempurna \\
\hline $0<$ GR $<0,4$ & Ketimpangan Rendah \\
\hline $0,4<$ GR $<0,5$ & Ketimpangan Sedang \\
\hline $0,5<$ GR $<1$ & Ketimpangan Tinggi \\
\hline GR $=1$ & Ketimpangan Sempurna \\
\hline
\end{tabular}

Ketimpangan distribusi ini digambarkan dengan Gini Ratio yang persebarannya dapat dilihat pada gambar di bawah ini.

\section{Gambar 1}

\section{Perkembangan Gini Ratio Sumatera Utara}

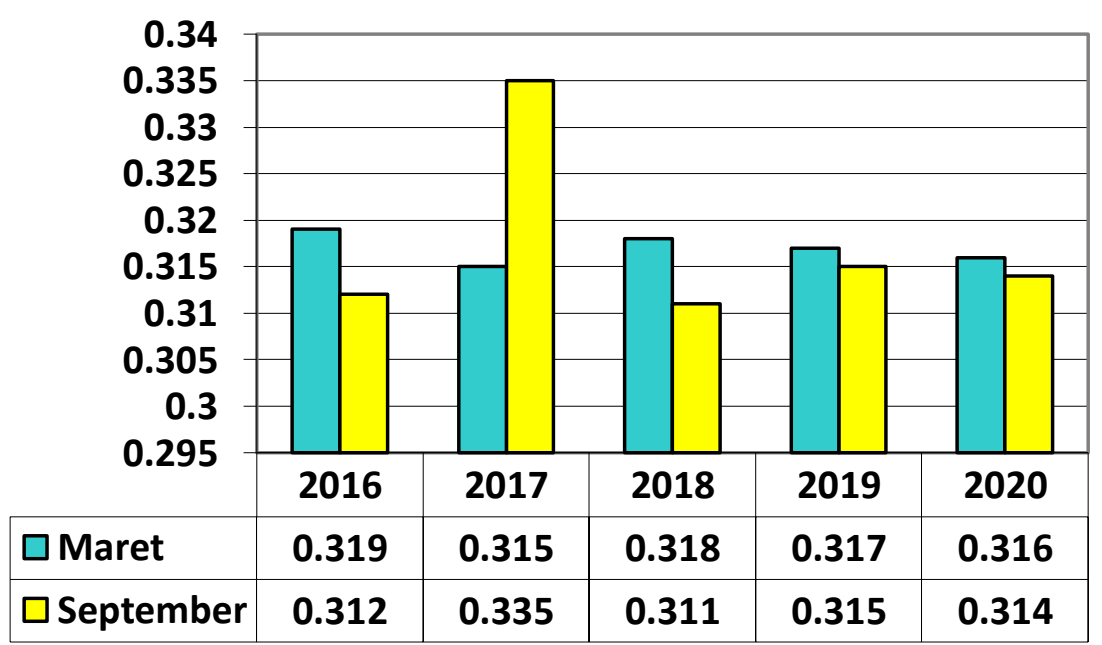

Sumber : BPS Sumatera Utara 
Ketimpangan distribusi pendapatan untuk Provinsi Sumatera Utara mengalami fluktuasi dari tahun ketahun. Pada Maret 2016, angka Gini Rasio Sumatera Utara sebesar 0,319, selama kurun waktu enam bulan, pada September 2016 mengalami banyak penurunan sebesar 0,007 menjadi 0,312. Pada September 2017, tingkat ketimpangan pendapatan penduduk Sumatera Utara yang diukur oleh Gini Ratio tercatat sebesar 0,335. Angka ini meningkat sebesar 0,020 poin jika dibandingkan dengan Gini Ratio Maret 2017 yang sebesar 0,315. Pada Maret 2017, angka Gini Rasio Sumatera Utara sebesar 0,315, selama kurun waktu satu tahun, pada Maret 2018 mengalami sedikit peningkatan sebesar 0,003 menjadi 0,318. Apabila dibandingkan secara nasional, angka Gini Rasio Sumatera Utara lebih rendah dibandingkan dengan angka Gini Rasio Indonesia. Gini ratio Indonesia pada Maret 2018 sebesar 0,318. Pada Maret 2019, Gini Ratio Sumatera Utara tercatat sebesar 0,317. Terjadi peningkatan sebesar 0,006 poin jika dibandingkan September 2018 yang sebesar 0,311. Pada Maret 2020, Gini Ratio Sumatera Utara tercatat sebesar 0,316 . Terjadi sedikit peningkatan sebesar 0,001 poin jika dibandingkan September 2019 yang sebesar 0,315. Peningkatan Gini Rasio ini berarti terjadi kenaikan tingkat ketimpangan pendapatan. Diakhir tahun 2020, tepatnya September 2020 Gini Ratio mengalami penurunan sebesar 0,002 yang menjadi 0,314 .

Jika dilihat dari koefisien gininya, dimana koefisien gini di Sumatera Utara pada September 2017 mencapai 0,335 dimana koefisien ini lebih tinggi dari tahun sebelumnya dan sesudahnya. Artinya, tahun 2017 distribusi pendapatan di Sumatera Utara mengalami ketimpangan distribusi pendapatan yang lebih tinggi dari tahun-tahun yang lain. Dan yang terendah ada pada September 2018 yaitu sebesar 0,311 .

\section{KESIMPULAN DAN SARAN KESIMPULAN}

Berdasarkan uraian di atas yang mengungkapan analisis kemiskinan dan distribusi pendapatan di Sumatera Utara (Tahun 2016-2020), maka dapat disimpulkan bahwa jumlah penduduk miskin dan presentase penduduk miskin selama tahun 2016-2019 mengalami penurunan yang signifikan. Namun selama pada tahun 2020 jumlah penduduk miskin mengalami peningkatan sebesar 76,71 ribu jiwa dengan jumlah presentase penduduk miskin sebesar $0,05 \%$. Ketimpangan distribusi pendapatan Provinsi Sumatera Utara yang dilihat dari Gini Ratio selama lima tahun pengamatan rata-rata koefisien berada di atas angka 0,310 yang artinya ketimpangan di Provinsi Sumatera Utara masih tergolong rendah $(0<\mathrm{GR}<0,4)$ 
karenanya pembangunan ekonomi dan distribusi pendapatan di Provinsi Sumatera Utara relatif merata, dan nilai Gini Ratio tertinggi selama tahun pengamatan terjadi di September 2017.

\section{SARAN}

Berdasarkan kesimpulan penelitian, adapun saran yang dapat disampaikan adalah pemerintah harus berupaya untuk mengurangi kemiskinan dan ketimpangan distribusi pendapatan di Provinsi Sumatera Utara. Jika dilihat dari Gini Ratio selama lima tahun ketimpangan ekonomi dan distribusi pendapatan di Provinsi Sumatera Utara relatif merata, namun tetap saja pemerintah harus waspada terhadap hal tersebut apabila terjadinya kenaikan. Selain itu, pemerintah juga harus meningkatkan percepatan pembangunan dalam berbagai hal terutama di wilayah Provinsi Sumatera Utara yang masih tertinggal dengan yang lainnya.

\section{DAFTAR PUSTAKA}

Badan pusat statistik Sumatera Utara. 2016. Profil Kemiskinan Provinsi Sumatera Utara 2016. Sumatera Utara: Badan Pusat Statistik.

Badan pusat statistik Sumatera Utara. 2017. Profil Kemiskinan Provinsi Sumatera Utara 2017. Sumatera Utara: Badan Pusat Statistik.

Badan pusat statistik Sumatera Utara. 2018. Profil Kemiskinan Provinsi Sumatera Utara 2018. Sumatera Utara: Badan Pusat Statistik.

Badan pusat statistik Sumatera Utara. 2019. Profil Kemiskinan Provinsi Sumatera Utara 2019. Sumatera Utara: Badan Pusat Statistik.

Badan pusat statistik Sumatera Utara. 2020. Profil Kemiskinan Provinsi Sumatera Utara 2020. Sumatera Utara: Badan Pusat Statistik.

HAKIKI, F. M. (2015). Ketimpangan Distribusi Pendapatan Rumah Tangga Masyarakat Perkotaan (Kasus Kecamatan Banjarsari Kota Surakarta) [UNIVERSITAS DIPONEGORO SEMARANG]. In Skripsi. http://eprints.undip.ac.id/47181/1/04_HAKIKI.pdf

Hikmah, A. N. (2021). Analisis Pengaruh Investasi, Indeks Pembangunan Manusia Dan Jumlah Penduduk Terhadap Ketimpangan Distribusi Pendapatan Di Kota Surabaya Tahun 2011-2018 [Universitas 17 Agustus 1945 Surabaya]. http://repository.untagsby.ac.id/7815/

Hanum, Nurlaila. (2018). ANALISIS KEMISKINAN DAN KETIMPANGAN DISTRIBUSI PENDAPATAN WILAYAH DI KOTA LANGSA (STUDI KASUS GAMPONG 
MATANG SEULIMENG. Jurnal Samudra Ekonomika. 2(2). 157-170. https://ejurnalunsam.id

Jamal, Abd, Muhammad Reza, dan T.Zulham. (2019). ANALISIS KETIMPANGAN PEMBANGUNAN DAN DISTRIBUSI PENDAPATAN WILAYAH DI PROVINSI ACEH. Jurnal Ekonomi Dan Kebijakan Publik Indonesia. 6(1). 17-32. http://www.jurnal.unsiyah.ac.id

Mukhamad, B. S. (2018). Analisis Faktor-Faktor Yang Mempengaruhi Kemiskinan Di Kabupaten Ponorogo [Universitas Muhammadiyah Ponorogo]. http://eprints.umpo.ac.id/4030/

Prawoto, N. (2019). Strategi dan Kebijakan Pengentasan Kerniskinan. Lembaga Penelitian, Publlkasi, dan Pengabdian Masyarakat (LP3M). http://repository.umy.ac.id/bitstream/handle/123456789/35371/Bidang C.5- Nano P.pdf?sequence $=1 \&$ isAllowed $=\mathrm{y}$

Tiara, S. (2016). ANALISIS KETIMPANGAN DISTRIBUSI PENDAPATAN DI PROPINSI SUMATERA UTARA. Ekonomikawan: Jurnal Ilmu Ekonomi Dan Studi Pembangunan, 16(1), 1-16. https://doi.org/10.30596/ekonomikawan.v16i1.1013 